\title{
DERMATOGLYPHICS STUDY OF TUBERCULOSIS PATIENTS AND ITS CORRELATION WITH NORMAL PERSONS IN SOUTHERN (HADOTI REGION), RAJASTHAN
}

\author{
Manisha Jelia1, William Feroze Masih², Babu Lal Bansiwal', Jagmohan Sharma4, Kunj Bihari Rathore \\ ${ }_{1}^{1}$ Senior Demonstrator, Department of Anatomy, Government Medical College, Kota, Rajasthan. \\ ${ }^{2}$ Associate Professor, Department of Anatomy, Government Medical College, Kota, Rajasthan. \\ ${ }^{3}$ Assistant Professor, Department of TB \& Chest, Government Medical College, Kota, Rajasthan. \\ ${ }^{4}$ Retired Professor, Department of Anatomy, Government Medical College, Kota, Rajasthan. \\ ${ }^{5} P G$ Resident, Department of Anatomy, Government Medical College, Kota, Rajasthan.
}

\section{ABSTRACT}

\section{BACKGROUND}

Dermatoglyphics is a scientific study of epidermal ridges and their configuration on palmar and sole region. Dermatoglyphics had proved its importance in medicolegal, anthropological and in clinical fields. Abnormal dermatoglyphic pattern has been in many non-chromosomal genetic disorder and other diseases whose aetiology may be influenced directly or indirectly by genetic disorder. The tuberculosis is partly genetic and partly environmental. The genetic contribution is one of the causes of pulmonary tuberculosis. Tuberculosis caused by mycobacterium tuberculosis. So an attempt has been made to study Dermatoglyphic patterns in pulmonary tuberculosis patients and to compare them with normal individuals.

\section{AIMS AND OBJECTIVES}

To compare the dermatoglyphics patterns of pulmonary tuberculosis patients with normal individuals, both qualitative and quantitative.

\section{MATERIAL AND METHODS}

Dermatoglyphics prints of total 100 (Male 67 and Female 33) pulmonary tuberculosis patients (Sputum Positive) and 100 normal individuals (Male 66, Female 34) from July 2013 to June 2014 were studied qualitatively and quantitatively: Dermatoglyphic printing was done by using older and fairly good "Indian Ink Method." (Cummins and Midlo, 1961).

\section{RESULTS}

TFRC of pulmonary tuberculosis significantly high $(140.77 \pm 39.63)$ as compared to TFRC of normal $(115.02 \pm 39.63)$ and has high $\%$ of whorl and low \% of loops as compared to normal. P value is significant in whorl and loops and TFRC.

\section{CONCLUSION}

Racial and genetic factors play important roles in deciding the qualitative and quantitative patterns of dermatoglyphics. Gen etic contribution is one of the causes of pulmonary tuberculosis. Further quantitative study is needed to confirm the findings of present study.

\section{KEYWORDS}

Dermatoglyphics, Genetics, Pulmonary Tuberculosis, Palmar Dermatoglyphics, Palmar Prints.

HOW TO CITE THIS ARTICLE: Jelia M, Masih WF, Bansiwal BL, et al. Dermatoglyphics study of tuberculosis patients and its correlation with normal persons in southern (Hadoti region), Rajasthan. J. Evolution Med. Dent. Sci. 2016;5(27):1387-1390, DOI: $10.14260 /$ jemds/2016/327

\section{INTRODUCTION}

Dermatoglyphics is the study of surface markings of the skins, especially of the palms and sole region. The study of Dermatoglyphics was pioneered long back by Galton (1892). ${ }^{1}$ Palmar creases develop during the $2^{\text {nd }}$ and $3^{\text {rd }}$ month of intrauterine life and are not influenced by movement of hand in utero. ${ }^{2}$ Dermatoglyphics has proved its importance in medicolegal, anthropological and in clinical fields. They are of considerable clinical interest, because they are affected by certain abnormalities of early development including genetic disorders. Dermatoglyphic abnormalities have been found in many conditions associated with chromosomal aberrations in genetically and non-genetically transmitted disorders.

Financial or Other, Competing Interest: None.

Submission 15-02-2016, Peer Review 10-03-2016,

Acceptance 16-03-2016, Published 02-04-2016.

Corresponding Author:

Dr. William Feroze Masih,

$2 K-9$, Rangbari Road,

Kota-324005, Rajasthan.

E-mail: dr.williammasih@yahoo.com

DOI: $10.14260 /$ jemds $/ 2016 / 327$
Studies on families have shown that dermatoglyphics have a genetic basis but the number, type and interrelationship of genes concerned are not explicable yet. Medical dermatoglyphics scrutinizes palm print for clues to hereditary diseases. Abnormal dermatoglyphic pattern has been in many non-chromosomal genetic disorder and other diseases whose aetiology may be influenced directly or indirectly by genetic disorder. 2,3

The genetic contribution is one of the causes of pulmonary tuberculosis, tuberculosis caused by mycobacterium tuberculosis. Susceptibility to pulmonary tuberculosis in India has been linked to Mannose Binding Protein Gene. ${ }^{4}$ Significant association has been found between IL-1 Gene clusters and host susceptibility to tuberculosis. ${ }^{5}$ The tuberculosis is partly genetic and partly environmental. ${ }^{6}$

So an attempt has been made to study Dermatoglyphic patterns in pulmonary tuberculosis and to compare them with normal individuals. Considering all above facts, the present study is undertaken to find out various Dermatoglyphic features in pulmonary tuberculosis patients and compare them with normal individuals. Result found whether are statistically significant or not. 


\section{AIMS AND OBJECTIVES}

1. To compare the dermatoglyphics pattern of pulmonary tuberculosis with normal, both qualitatively and quantitatively.

a. Qualitative parameters are Digital pattern of ridges (a) Arch, (b) Loop, (c) Whorl, (d) Composite.

b. Quantitative parameters are: 1 . Ridge counting, 2. Total finger ridge count (TFRC).

2. To predict possibility of disease occurrence in individual with particular finger print pattern.

\section{MATERIAL AND METHODS}

Dermatoglyphics prints of the 100 (Male-67, Femal-33) patients diagnosed as Tuberculosis (Sputum Positive) were taken from TB and Chest Department of New Medical College Hospital, Kota and 100 were normal individuals (Male-66, Female 34) as control from July 2013 to June 2014 were studied.

Patients age range from 25 to 75 years including both male and female. Control group were of same age and sex, who had never suffered from tuberculosis in past or having any symptoms of disease. Patients with disease like Leprosy, Burn, Bronchial Asthma, Coeliac Disease or CHD were not included.

Informed written consent from all eligible patients were taken. Dermatoglyphic printing was done by using older and fairly good "Indian Ink Method." (Cummins and Midlo, 1961). ${ }^{7}$

Ordinary white paper with size of A4 size, Thumb impression ink (Kores). Roller for spreading the ink over a glass plate, inking slab, a round bottle is used for printing the palm. A magnifying glass lens of power $10 \mathrm{X}$ is used for studying small prints.

\section{Procedure for Inking and Printing}

First hands are washed with soap and water and the greasy material is cleared off with the help of ether. A small dab of printer's ink is squeezed out on the inking slab and is spread into thin even film with the help of a roller for direct inking of the fingers. Palm is smeared uniformly with the inked roller to cover the whole area of the palm to be printed for examination.

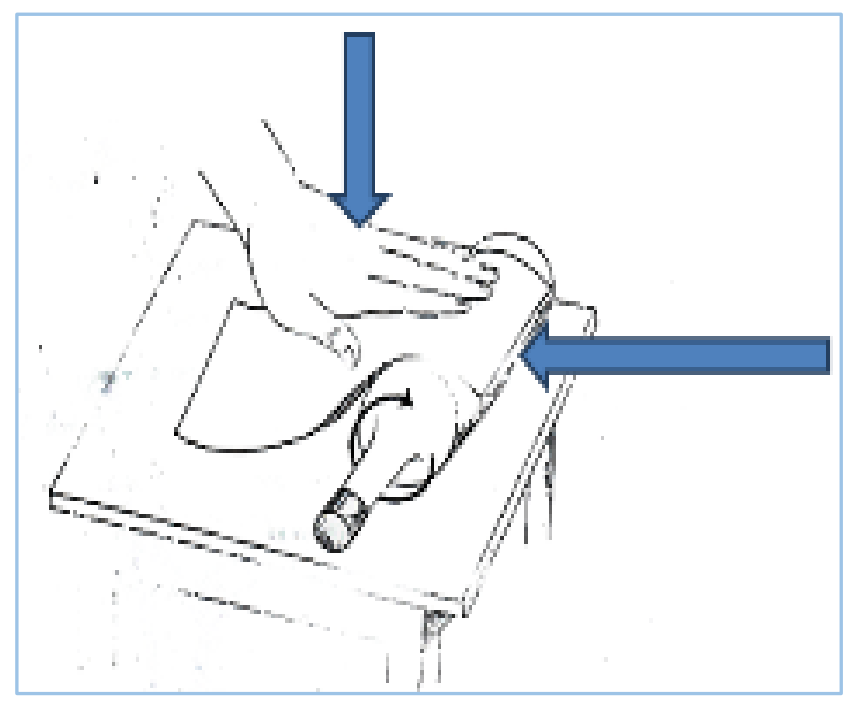

Picture 1: Technique of Taking Palm Print

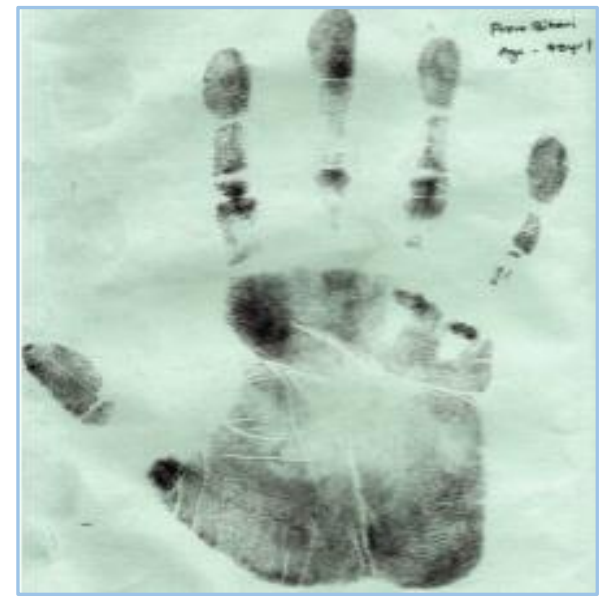

\section{Photo 1: Showing palm print Left hand of 40 year Male}

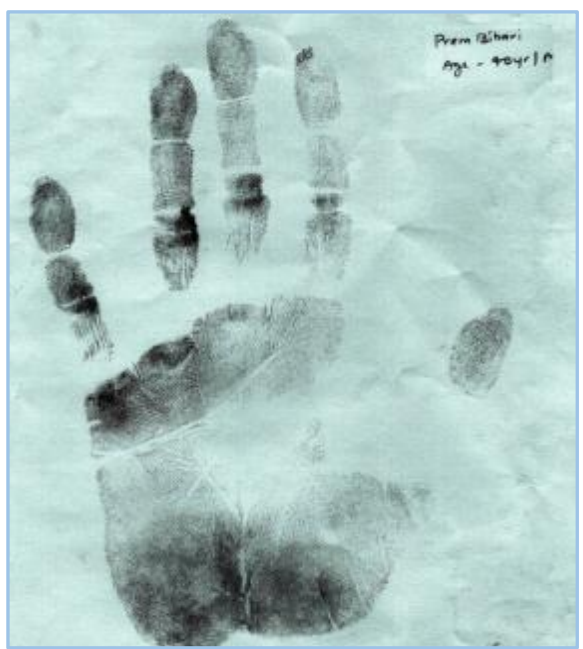

Photo 2: Showing palm print Right hand of 40 year Male

\section{OBSERVATION}

Dermatoglyphics prints of the 100 (Male-67, Female-33) patients diagnosed as Tuberculosis (Sputum Positive) were taken from TB and Chest Department of New Medical College Hospital, Kota and 100 were normal individuals (Male-66, Female-34), were studied in Department of Anatomy of Govt. Medical College, Kota.

The data collected in so far was entered into a database. Statistical processing and various calculations were performed with Statistical software for $\mathrm{z}$ test and $\mathrm{p}$ test.

\begin{tabular}{|c|c|c|c|c|}
\hline Status & Number & Mean & SD & p-value \\
\hline Control & 100 & 115.02 & 39.63 & \multirow{2}{*}{$<0.05$} \\
\hline Patients & 100 & 140.77 & 42.76 & \\
\cline { 1 - 1 } & Table 1: Comparison of Mean TFRC by Status \\
\hline
\end{tabular}

Table 1 shows the mean TFRC of patients is found to be significantly high $(140.77 \pm 39.63)$ as compared to TFRC of controls (115.02 \pm 39.63$)$.

\begin{tabular}{|c|c|c|c|c|}
\hline Status & $\leq \mathbf{7 5}$ & $\mathbf{7 6 - 1 5 0}$ & $\mathbf{2 1 5 1}$ & Total \\
\hline Control & 14 & 65 & 21 & 100 \\
\hline Patients & 6 & 52 & 42 & 100 \\
\hline Total & $\mathbf{2 0}$ & $\mathbf{1 1 7}$ & $\mathbf{6 3}$ & $\mathbf{2 0 0}$ \\
\hline \multicolumn{5}{|c|}{ Table 2: Distribution of Subjects } \\
according to their Status \& TFRC \\
\hline
\end{tabular}


Table 2 shows the distribution of TFRC among pulmonary tuberculosis patients and controls. The distribution was not significantly different between patients and controls. It can be seen from the table that middle values (76-150) were associated with patients as well as control.

\begin{tabular}{|c|c|c|c|c|c|c|c|c|c|c|c|c|}
\hline & & \multicolumn{2}{|c|}{ I } & \multicolumn{2}{|c|}{ II } & \multicolumn{2}{|c|}{ III } & \multicolumn{2}{|c|}{ IV } & \multicolumn{2}{|c|}{$\mathbf{V}$} & \\
\hline & & Right & Left & Right & Left & Right & Left & Right & Left & Right & Left & \\
\hline \multirow{5}{*}{ Patients } & Whorl & 63 & 54 & 60 & 61 & 46 & 52 & 61 & 69 & 36 & 25 & 52.7 \\
\hline & Ulnar Loop & 34 & 45 & 27 & 22 & 46 & 44 & 35 & 30 & 60 & 73 & 41.6 \\
\hline & Radial Loop & 0 & 0 & 10 & 4 & 1 & 0 & 0 & 0 & 0 & 0 & 1.5 \\
\hline & Arch & 3 & 1 & 3 & 13 & 7 & 4 & 4 & 1 & 4 & 2 & 4.2 \\
\hline & Composite & 0 & 0 & 0 & 0 & 0 & 0 & 0 & 0 & 0 & 0 & 0 \\
\hline \multirow{5}{*}{ Control } & Whorl & 52 & 41 & 28 & 17 & 17 & 13 & 37 & 30 & 12 & 2 & 24.9 \\
\hline & Ulnar Loop & 47 & 51 & 50 & 66 & 78 & 81 & 62 & 65 & 87 & 94 & 68.1 \\
\hline & Radial Loop & 0 & 3 & 8 & 6 & 0 & 1 & 0 & 1 & 0 & 0 & 1.9 \\
\hline & Arch & 0 & 4 & 12 & 10 & 5 & 5 & 0 & 3 & 1 & 4 & 4.4 \\
\hline & Composite & 1 & 1 & 2 & 1 & 0 & 0 & 1 & 1 & 0 & 0 & 0.7 \\
\hline
\end{tabular}

\begin{tabular}{|c|c|c|c|c|}
\hline Status & Arch & Loop & Whorl & Composite \\
\hline Control & 4.4 & 70 & 24.9 & 0.7 \\
\hline Patients & 4.2 & 43.1 & 52.7 & 0 \\
\hline p-Value & - & $<0.05$ & $<0.05$ & - \\
\hline \multicolumn{5}{|c|}{ Table 4: Dermatoglyphic Patterns } \\
in Patients and Control (In \%)
\end{tabular}

Table 4 shows patients has high \% of whorl and control has high \% of loops, p value is significant in whorl and loops.

\section{FINGERTIP PATTERNS}

\section{Whorls}

Table 4 shows there is a significant increase in the whorl pattern in pulmonary tuberculosis patients $(52.2 \%)$ as compared to controls (22.8\%) in left hand and 53\% and $29.2 \%$ in right hand respectively. The frequency of whorls in pulmonary tuberculosis (Table 3) patients vs. controls areRight thumb (63\% vs. 52\%); Left thumb (54\% vs. $41 \%$ ); Left index finger (61\% vs. $17 \%$ ); Right index finger (60\% vs. $28 \%$ ); Left middle finger ( $52 \%$ vs. $13 \%$ ); Right middle finger (46\% vs. $17 \%$ ); Left ring finger (69\% vs. 30\%); Right ring finger $(61 \%$ vs. $37 \%$ ); Left little finger ( $25 \%$ vs. $2 \%$ ) and Right little finger $(36 \%$ vs. $12 \%)$. Significant rise in whorl pattern $(\mathrm{p}<0.05)$ found.

\section{Ulnar Loops}

There is a significant decrease of ulnar loops pattern in pulmonary Table 4 , Tuberculosis patients $40.6 \%$ compared to $64.8 \%$ controls in right hand and $42.7 \%$ and $71.4 \%$ in left hand respectively. The difference is significant $(\mathrm{p}<0.001)$ for ulnar loops in right hand of pulmonary tuberculosis patients.

Table 3 right thumb (34\% vs. $47 \%$ ); left thumb (45\% vs. $51 \%$ ); left index finger ( $22 \%$ vs. $66 \%$ ); right index finger $(27 \%$ vs. $50 \%$ ); right middle finger ( $46 \%$ vs. $78 \%$ ); left middle finger ( $44 \%$ vs. $81 \%$ ); left ring finger ( $30 \%$ vs. $65 \%$ ); right ring finger DISCUSSION
(35\% vs. 62\%); left little finger (73\% vs. 94\%) and right little finger (60\% vs. $87 \%$ ).

\section{Radial Loops}

Table 4 shows fall in the percentage of radial loops in pulmonary tuberculosis patients $(0.8 \%)$ as compared to normal (2.2\%) Table 3 shows in left hand and $2.2 \%$ and $1.6 \%$ in right hand respectively. In left thumb (0\% vs. $3 \%)$; right thumb ( $0 \%$ vs. $0 \%$ ); left index finger ( $4 \%$ vs. $6 \%$ ); right index finger ( $10 \%$ vs. $8 \%)$; left middle finger ( $0 \%$ vs. $1 \%)$; right middle finger ( $1 \%$ vs. $0 \%$ ); left ring finger $(0 \%$ vs. $1 \%)$; right ring finger ( $0 \%$ vs. $0 \%)$; left little finger ( $0 \%$ vs. $0 \%$ ) and right little finger ( $0 \%$ vs. $0 \%)$.

\section{Arches}

Table 4 shows there is no significant change in arch pattern in pulmonary tuberculosis patients $(4.2 \%)$ as compared to controls (5.2\%) in left hand and $4.2 \%$ and $3.6 \%$ in right hand respectively. Table 3 shows Left thumb (1\% vs. 4\%), right thumb (3\% vs. $0 \%$ ), left index finger (13\% vs. $10 \%)$, right index ( $3 \%$ vs. $12 \%$ ), left middle finger ( $4 \%$ vs. $5 \%$ ), right middle finger ( $7 \%$ vs. $5 \%)$, left ring finger (1\% vs. $3 \%)$, right ring finger ( $4 \%$ vs. $0 \%$, left little finger ( $2 \%$ vs. $4 \%$ ) and right little finger ( $4 \%$ vs. $1 \%$ ).

\begin{tabular}{|c|c|c|c|c|}
\hline Status & Number & Mean & SD & p-value \\
\hline Control & 100 & 115.02 & 39.63 & \multirow{2}{*}{$<0.05$} \\
\hline Patients & 100 & 140.77 & 42.76 & \\
\hline \multicolumn{7}{|c|}{ Table 5: Total Finger Ridge Count (TFRC) } \\
\hline
\end{tabular}

Table 5 shows that mean TFRC in Tuberculosis patients is found to be significantly high $(140.77+39.63)$ as compared to TFRC of normal $(115.02+39.63)$.

\begin{tabular}{|c|c|c|c|c|c|c|}
\hline \multirow[t]{2}{*}{ Author } & \multicolumn{4}{|c|}{ Fingertip Pattern } & \multirow[t]{2}{*}{ TFRC } & \multirow[t]{2}{*}{ P-value } \\
\hline & Whorls & Ulnar Loop & Radial Loop & Arches & & \\
\hline Sangita B et al. ${ }^{8}$ & $56.6 \%$ & $32 \%$ & - & $11.3 \%$ & 112.4 & $\begin{array}{l}\quad(\mathrm{P}<0.05) \\
\text { Highly significant }\end{array}$ \\
\hline Geetha V et al. ${ }^{9}$ & $60.6 \%$ & $36.4 \%$ & & $3 \%$ & - & Highly significant \\
\hline Nechaeva et al. 10 & - & - & - & - & - & $\begin{array}{c}\text { Statistically } \\
\text { significant }\end{array}$ \\
\hline Sidhu LS et al. ${ }^{11,12}$ & - & - & - & - & - & Statistically not significant \\
\hline Jagdish Choudhary et al.13 & $34.4 \%$ & $59.3 \%$ & $2.2 \%$ & $4 \%$ & - & Statistically not significant \\
\hline Present Study & $52.7 \%$ & $43.1 \%$ & $.8 \%$ & $4.2 \%$ & $(140.77)$ & $\begin{array}{c}(\mathrm{P}<0.05) \\
\text { Highly significant }\end{array}$ \\
\hline & & Comnars & Id of $F i$ & ins $P o$ & \& TFRC & \\
\hline
\end{tabular}


In our study, there is a significant increase in the whorl pattern in pulmonary tuberculosis patients $(52.2 \%)$ as compared to controls (22.8\%) in left hand and 53\% and 29.2\% in right hand respectively. There is a significant decrease of ulnar loops pattern in pulmonary tuberculosis patients $40.6 \%$ compared to $64.8 \%$ controls in right hand and $42.7 \%$ and $71.4 \%$ in left hand respectively. The difference is significant $(\mathrm{p}<0.001)$.

There is fall in the percentage of radial loops in pulmonary tuberculosis patients $(0.8 \%)$ as compared to normal $(2.2 \%)$ in left hand and $2.2 \%$ and $1.6 \%$ in right hand respectively.

There is no significant change in arch pattern in pulmonary tuberculosis patients $(4.2 \%)$, as compared to controls (5.2\%) in left hand and $4.2 \%$ and $3.6 \%$ in right hand respectively.

The mean TFRC in Tuberculosis patients is found to be significantly high $(140.77+39.63)$ as compared to TFRC of normal $(115.02+39.6)$.

Table 6 shows that our study is in accordance with Sangita et al. ${ }^{9}$ Nechaeva et al. ${ }^{10}$ Geetha $V$ et al. ${ }^{11}$ which is highly statistically significant $(\mathrm{P}<0.05)$, but it is different than Sidhu LS et al.7,8 and Choudhary J. et al. ${ }^{13}$ who observed no statistical significant differences in finger print patterns in pulmonary tuberculosis patients compared with controls. These observations can be an additional supports in diagnosis patients of pulmonary tuberculosis.

\section{CONCLUSION}

Dermatoglyphic patterns are affected by various factors. Racial and genetic factors play important roles in deciding the qualitative and quantitative patterns of dermatoglyphics. Our aim was to find out a definite correlation between dermatoglyphics in pulmonary tuberculosis. We cannot label one factor as a single absolute factor, so it is difficult to find out absolute and independent correlation with the disease, but nevertheless a corroborative value is of concordant importance.

The current status of dermatoglyphics is such that the diagnosis of some illness can now be done on the basis of dermatoglyphic analysis alone and currently several dermatoglyphic researchers claim a high degree of accuracy in their prognostic ability from the hand features.

1. A significant increase $(\mathrm{p}<0.05)$ in the whorl pattern in pulmonary tuberculosis patients $(52.7 \%)$ as compared to normal (24.9\%).

2. A significantly lower $(\mathrm{P}<0.05)$ in the loop pattern in pulmonary tuberculosis patients $(43.1 \%)$ as compared to normal $(70 \%)$.
3. The mean TFRC of tuberculosis patients is found to be significantly high $(140.77+39.63)$ as compared to TFRC of normal $(115.02+39.63)$.

Genetic contribution is one of the causes of pulmonary tuberculosis. We recommend further quantitative study to confirm the findings of present study.

\section{REFERENCES}

1. Galton F, Cummins H, Midlow C. The palmar and plantar epidermal ridge configuration in European Americans. Am J Phy Anthropol 1926;9(4):471-502.

2. Achs R, Harper RG, Siegel M. Unusual dermatoglyphic findings associated with rubella embryopathy. New Eng J Med 1966;274(3):148-150.

3. Gupta CM, Tutakne MA, Bhanu BV. Absence of triradius d on palm of leprosy patients. Indian J Lepr 1984;56(4):8524.

4. Schauman B, Alter $M$ dermatoglyphics in medical disorders. New York Springer - Verlag, 1976;1st ed:p 7.

5. Selvaraj P, Narayanan PR, Reetha AM. Association of mannose binding protein gene with susceptibility to pulmonary tuberculosis. Tuber Lung Dis 1999;79(4):2217.

6. Bellamy R, Ruwende C, Corrah T. Assessment of the interleukin 1 gene cluster and other candidate gene polymorphisms in host susceptibility to tuberculosis. Journal of infectious disease 1998;79(2):83-9.

7. Cummins H, Midlo C. Finger prints palms and soles, an introduction to dermatoglyphics. Dover Publications Inc New York 1961;36(3):78-81.

8. Sangita S Babu, Powar BP, Khare ON. Palmar dermatoglyphics in pulmonary tuberculosis. J Anat Soc India 2005;54(2):1-9.

9. Vishwanathan G, Krishnan M, Kalyani GS. Analysis of fingertip dermatoglyphics of tuberculosis patients. Journal of Ecobiology York 2002;14(3):205-210.

10. Nechaeva OB, Polzik EV, Iakusheva MIu, et al. The dermatoglyphics of patients with different forms of tuberculosis of the respiratory organs. Tsitol Genet 1996;30(6):65-9.

11. Sidhu LS, Bhatnagar DP, Malhotra R, et al. Association of finger ball dermatoglyphics with pulmonary tuberculosis. Anthropol Anz 1977;36(1):36-42.

12. Sidhu LS, Sharma A, Singal P, et al. A study of relationship between pulmonary tuberculosis and palmar dermatoglyphic traits. Anthropol Anz 1978;36(3):219-23.

13. Choudhary J, Sarviya B, Patel SV, et al. A study of palmar dermatoglyphics of pulmonary tuberculosis patients in Bhavnagar district. NJIRM 2011;2(2):50-52. 